\title{
Strategi Pemberdayaan Masyarakat Kawasan Penyangga yang Tepat di TN Sebangau Berdasarkan Perspektif Sustainable Livelihood Approach
}

\author{
Ardiyanto Maksimilianus Gai \\ Program Studi Perencanaan Wilayah dan Kota, Institut Teknologi Nasional Malang, Jl. Bendungan Sigura-gura No. 02, Malang, Jawa Timur \\ ardiyanto maksimilianus@lecturer.itn.ac.id
}

\begin{tabular}{l}
\hline \hline INFO ARTIKEL \\
\hline Riwayat Artikel: \\
Diterima: $10-07-2020$ \\
Disetujui: $29-08-2020$ \\
\end{tabular}

\section{Kata Kunci:}

Pemberdayaan

Masyarakat

Kawasan Penyangga

Sustainable Livelihood

TN Sebangau

\begin{abstract}
ABSTRAK
Abstrak: Kawasan penyangga di TN Sebangau memiliki permasalahan dari berbagai sektor, seperti sosial, ekonomi dan lingkungan. Salah satunya adalah masalah kerusakan hutan. Saat ini masyarakat yang tinggal di kawasan penyangga TN Sebangau bergantung pada hasil sumber daya alamnya. Namun, kesejahteraan yang rendah menuntut masyarakat untuk melakukan beberapa kegiatan yang melanggar kebijakan TN Sebangau dan berpotensi mengganggu lingkungan sekitarnya. Konsep pendekatan mengenai penghidupan yang berkelanjutan (sustainable livelihood) merupakan salah satu bentuk metode yang dapat mengatasi permasalahan yang muncul pada masyarakat yang tinggal di kawasan penyangga TN Sebangau. Penelitian ini menggunakan pendekatan deskriptif kualitatif, dengan menggunakan metode skoring, AHP dan analisis triangulasi. Subjek penelitian adalah masyarakat yang tinggal di kawasan penyangga TN Sebangau. Variabel yang digunakan adalah modal sosial, modal alam, modal fisik, modal manusia dan modal finansial. Hasil penelitian menunjukkan dari kriteria dan subkriteria pada 3 strategi, yaitu pengembangan masyarakat lokal, perencanaan sosial dan aksi sosial, kriteria 'pengembangan masyarakat lokal' merupakan model pemberdayaan yang tepat untuk diterapkan di kawasan penyangga TN Sebangau. Sehingga diperlukan strategi pengembangan yang sesuai dengan masingmasing variabel terkait penghidupan berkelanjutan (sustainable livelihood).
\end{abstract}

\begin{abstract}
Sebangau National Park buffer zone had problem in many sectors like social, economic and environment. One of them is deforestation. Currently, people who lived at Sebangau National Park buffer zone depends on it natural resources. However, low-welvare condition requires people doing some violation against Sebangau National Park policy and potentially interfere the ecosistem. Sustainable livelihood approach presumed can be one solution to solve the problem at Sebangau National Park buffer zone. This research used qualitative descriptive approach, with scoring method, AHP and triangulation analysis. Research subject is people who lived at Sebangau National Park buffer zone. Variabel that used is social capital, natural capital, physical capital, human capital and financial capital. The results showed that from criteria and sub criteria on 3 strategy, that is local community development strategy, social planning strategy and social action strategy, local community development criteria is exactly empowerment model to apply at Sebangau National Park buffer zone. So that the development strategy of the models are needed in accordance with each variable related to sustainable livelihood.
\end{abstract}

\section{A. LATAR BELAKANG}

Indonesia masuk dalam salah satu negara dengan luas hutan tertinggi di dunia. Indonesia memiliki sekitar 2\% dari total tutupan hutan dunia, setara dengan 92 juta hektar. Saat ini, Pemerintah Indonesia mengklaim bahwa kerusakan hutan telah mengalami penurunan signifikan. Dimana kerusakan hutan secara global telah menurun sebesar 40\% dan Indonesia memberikan kontribusi dengan menangani kerusakan hutan sebesar 0,44 juta ha [1].

Namun hal tersebut tidak sesuai dengan data yang ada pada Kementerian Lingkungan Hidup dan
Kehutanan, dimana pada tahun 2017 hingga 2018, Indonesia kehilangan 493.300 ha dan hanya tertangani 53.900 ha dengan metode penanaman kembali. Sedangkan pada tahun 2018 hingga 2019, Indonesia kehilangan 465.500 ha tutupan hutan dan hanya tertangani dengan penanaman kembali sebesar 3100 ha [2].

Taman Nasional (TN) Sebangau merupakan kawasan pelestarian alam yang mempunyai hutan raya gambut dan dilewati oleh dua sungai (sungai Sebangau dan sungai Katingan) sehingga memiliki ekosistem yang asli dan perlu dilindungi. Saat ini masyarakat yang tinggal di kawasan penyangga TN Sebangau bergantung 
pada hasil sumber daya alamnya. Sebagian besar masyarakat bermata pencaharian nelayan dengan memanfaatkan ekosistem sungai, namun ada juga masyarakat yang memanfaatkan tumbuh-tumbuhan untuk dijadikan obat. Sebagian masyarakat memiliki mata pencaharian sebagai petani, namun lahan pertanian dibuka dengan cara ilegal yaitu pembakaran lahan. Pelanggaran lain yang sering dilakukan masyarakat kawasan penyangga adalah penebangan liar dan perburuan liar.

Pelanggaran dalam pengelolaan lahan di kawasan penyangga TN Sebangau ini dikarenakan kondisi kesejahteraan masyarakat kawasan penyangga masih sangat rendah. Kawasan penyangga TN Sebangau seringkali luput dari kebijakan pembangunan, hal ini dikarenakan kawasan penyangga tidak dianggap sebagai penggerak utama perekonomian kawasan. Untuk mengatasi pelanggaran yang terjadi, beberapa peraturan-peraturan telah ditetapkan dan diterapkan. Namun belum ada metode penanganan yang efektif dari penerapan peraturan tersebut agar masyarakat penyangga menjadi masyarakat yang mandiri dari aspek sumber daya manusia, sosial hingga ekonomi.

Perlu adanya konsep yang tepat untuk menanggulangi permasalahan yang ada pada kawasan penyangga TN Sebangau. Konsep pendekatan mengenai penghidupan yang berkelanjutan (sustainable livelihood approach/SLA) merupakan salah satu bentuk metode untuk meningkatkan pemahaman penghidupan rumah tangga dengan kesejahteraan rendah [3]. Pendekatan ini dipilih dikarenakan derajat pemenuhan kebutuhan sosial, ekonomi dan ekologi dilakukan secara adil dan seimbang dengan mengkombinasikan aktivitas dan utilisasi modal-modal yang ada dalam tata sistem kehidupan [4]. Diharapkan dengan konsep pendekatan ini akan membantu masyarakat penyangga di kawasan TN Sebangau menjadi lebih mendiri dan berdaya dalam upaya meningkatkan kesejahteraan serta menjaga kelestarian hutan.

Penelitian ini bertujuan untuk mendapatkan model pemberdayaan yang tepat untuk diterapkan pada masyarakat yang tinggal di kawasan penyangga TN Sebangau.

\section{B. METODE PENELITIAN}

Penelitian ini menggunakan pendekatan deskriptif kualitatif. Pendekatan ini dipilih untuk memahami kondisi sosial yang dialami subjek penelitian, yaitu masyarakat yang tinggal di kawasan penyangga TN Sebangau. Jenis sampling yang digunakan adalah purposive sampling, sehingga responden yang diwawancara dipilih dengan kriteria atau karakteristik tertentu. Peningkatan kualitas penelitian dilakukan menggunakan teknik triangulasi. Dimana pertanyaan dengan variabel yang sama ditanyakan pada orang yang berbeda untuk dibandingkan, dianalisis kemudian membentuk kesimpulan.
Variabel pokok yang ditanyakan kepada responden terkait penelitian antara lain :

a. Modal manusia : mata pencaharian masyarakat, jenis dan pola kerja

b. Modal sosial : norma atau nilai yang berlaku, mekanisme dan kearifan lokal

c. Modal finansial : sumber pendapatan dan nilai dari masing-masing sumber ekonomi

d. Modal fisik : aksesibilitas, kondisi rumah, ketersediaan air bersih, kondisi sanitasi dan drainase

e. Modal alam : karakteristik dan kondisi lingkungan sungai

\section{HASIL DAN PEMBAHASAN}

\section{Identifikasi Karakteristik Kawasan Penyangga TN Sebangau berdasarkan Perspektif Sustainable Livelihood}

Karakteristik sustainable livelihood dilihat berdasarkan modal manusia, modal sosial, modal finansial, modal fisik dan modal alam. Nilai yang dilihat adalah kondisi, keberadaan dan kemampuan masyarakat penyangga TN Sebangau dalam mengakses modal sesuai sustainable livelihood approach.

a. Modal manusia

Masyarakat yang tinggal di kawasan penyangga TN Sebangau, sebagian besar bermata penaharian sebagai nelayan. Sedangkan mata pencaharian lain adalah pegawai pemerintahan, pertanian dan perkebunan, perikanan, perdagangan dan peternakan.

Masyarakat yang bermata pencaharian sebagai nelayan dikategorikan menjadi nelayan asli dan nelayan pendatang. Nelayan asli merupakan nelayan yang berasar dari Desa Kereng Bangkirai. Sedangkan nelayan pendatang adalah merupakan nelayan yang datang dari luar wilayah desa atau luar wilayah Sungai Sebangau.

Pola kerja masyarakat nelayan ini terbagi menjadi 3, yaitu nelayan menetap, nelayan musiman dan nelayan komuter. Nelayan menetap merupakan nelayan yang tinggal sepanjang tahun di permukiman penangkapan ikan. Sedangkan nelayan musiman merupakan nelayan yang hanya datang saat musim penangkapan ikan. Sedangkan nelayan komuter merupakan nelayan yang tinggal di Desa Kereng Bangkirai namun saat pagi pergi ke lokasi pekerjaan dan sore hari kembali ke lokasi tinggal.

\section{b. Modal sosial}

Masyarakat di kawasan penyangga TN Sebangau bergantung pada sungai sebagai sumber mata pencaharian. Karakteristik sosial di kawasan ini berkaitan erat dengan pola penguasaan dan kepemilihan daerah tangkapan. Hal tersebut juga dipengaruhi oleh aturan dan mekanisme lokal yang terkait sumber daya alam. Peraturan dan mekanisme terkait pemanfaatan sumber daya alam antara lain :

1) Menggunakan istilah wilayah komunal dan keluarga 
2) Wilayah komunal bersifat umum, pada umumnya merupakan wilayah yang terhubung dengan sungai utama. Penguasaan komunal dilakukan oleh seluruh nelayan dengan ada norma-norma yang mengatur. Penguasaan wilayah komual hanya untuk kepentingan penangkapan ikan, sedangkan untuk lalu lintas sungai dapat dilalui dengan bebas

3) Wilayah keluarga bersifat tertutup, dengan tujuan melindungi mata pencaharian keluarga. Penguasaan dilakukan oleh keluarga dengan sistem tertentu yang dibuat oleh keluarga tersebut.

Terdapat beberapa kearifan lokal yang dilakukan oleh nelayan di TN Sebangau, namun tidak diterapkan oleh seluruh nelayan. Kearifan lokal tersebut antara lain :

1) Tidak boleh menancapkan alat pengayuh pada saat menangkap ikan, karena hal ini akan mengakibatlan hasil tangkapan berkurang

2) Tidak diperbolehkan menangkap induk ikan Toman, melepaskan kembali ikan kecil yang masuk ke alat tangkap dan melepaskan kembali ikan Toman dan ikan Tampahas jika beratnya $>5 \mathrm{~kg}$. Hal tersebut perlu dilakukan agar hasil tangkapan tidak berkurang

3) Tidak boleh menangkap ikan Tampahas yang sedang menetaskan telur dan tidak boleh merusak tempat bertelur dan tempat berkembang biak ikan karena akan mempengaruhi hasil tangkapan

4) Tidak boleh membuhuh ular air atau menangkap ikan Tampahas dengan dipukul atau dibacok karena darahnya akan mencemari air sungai

5) Melakukan ritual syukur dengan menenggelamkan 510 butir telur ayam atau hasil tangkapan akan berkurang

6) Tidak mengganggu ular atau buaya yang melintas

7) Tidak menangkap ikan pada hari Jumat

8) Tidak menangkap ikan pada hari awal puasa, hari raya atau pada awal bulan Syawal

9) Tidak bekerja saat ada keluarga yang meninggal dunia

\section{c. Modal finansial}

Pada kawasan penyangga TN Sebangau belum ada lembaga keuangan yang sesuai untuk mata pencaharian masyarakat, sehingga masyarakat masih kesulitan untuk mendapatkan dana untuk mengolah hasil produksi.

Selain sebagai nelayan, masyarakat di kawasan penyangga TN Sebangau juga melakukan pekerjaan lain untuk memenuhi kebutuhan sehari-hari. Pekerjaan tersebut antara lain :

1) Mengembangkan budidaya ikan tangkap dengan keramba sungai

2) Berburu rusa (mambajang) dengan menggunakan jerat atau perangkap

3) Berburu babi (manjarat bawui) dengan menggunakan jerat atau perangkap

4) Mencari kayu galam (manggalam), dimana kegiatan ini dilakukan saat musim banjir agar mudah saat membawa kayu
5) Mencari burung (mamburung/mangarindit)

6) Menyadap karet (mamantat), dimana kegiatan ini pada umumnya dilakukan pada saat musim kemarau

7) Mencari emas secara tradisional (manyedot), kegiatan ini dilakukan pada saat musim kemarau di Sungai Katingan atau Sungai Kahayan yang mulai surut.

\section{d. Modal fisik}

Kawasan penyangga TN Sebangau telah memiliki sarana dan prasarana, namun kualitas dari sarana dan prasarana tersebut perlu ditingkatkan. Sebanyak $85 \%$ masyarakat yang tinggal di kawasan penyangga tidak mampu menjangkau sarana dan prasarana perkotaan. Selain itu, sarana pendidikan, kesehatan dan peribadatan belum memnuhi standar pelayanan permukiman sebanyak $75 \%$.

Kondisi rumah atau pondok yang ada di kawasan permukiman terbagi menjadi temporer, semi permanen dan permanen. Pondok temporer dibangun apa adanya dan serba darurat, pada umumnya dibuat dari kayu dan beratap rumbia. Pondok temporer ini sering mengalami kebocoran, sehingga juga sering dilapisi dengan kain terpal. Sedangkan pondok semi permanen dibuat dari tiang kayu yang tahan lama dengan lantai atau dinding terbuat dari kayu tipis serta menggunakan atap dari rumbia. Pondok permanen merupakan pondok bagi nelayan yang tinggal menetap di desa. Dimana bangunan dibangun kokoh dengan tiang kayu yang kuat, dinding dan lantai dari kayu tebal dan menggunakan atap dari seng.

\section{e. Modal alam}

Kawasan sungai TN Sebangau telah memiliki oola penguasaan dan kepemilikan daerah tangkapan yang telah diatur dan ditaati. Pola tersebut mengatur hak kepemilikan yang memiliki konotasi memiliki, memasuki dan memanfaatkan.

Sungai utama yaitu Sungai Sebangau merupakan milik bersama sehingga siapa saja dapat mencari ikan di sungai ini, namun harus menggunakan norma penangkapan yang telah ditetapkan. Penguasaan teritorial di sungai utama, biasanya diawali dengan survey untuk mengetahui wilayah mana saja yang banyak ikannya. Kemudian disusul dengan pembangunan pondok darurat. Agar wilayah itu tidak dimasuki atau diambil oleh orang lain, maka sepanjang tahun harus ada yang tinggal di wilayah itu, entah dengan cara menetap atau bergiliran.

Rawa terbuka dan rawa tertutup merupakan area penghubung sungai utama dan anak sungai. Kawasan ini pada umumnya dipasang alat tangkapan yang dilakukan oleh pemilik sungai.

Anak dan cucu sungai di kawasan TN Sebangau pada umumnya ada yang memiliki. Dimana kepemilikan diawali dari orang yang bekerja pertama kali di anak atau cucu sungai tersebut, kemudian akan dilanjutkan 
oleh keturunannya. Pemilik memiliki kewenangan untuk mengatur dan mengawasi orang yang melakukan kegiatan di kawasan anak atau cucu sungai nya. Apabila ada sumber daya yang diambil dari kawasannya, maka pemilik sungai berhak mengambil pungutan.

Selanjutnya adalah tatas, merupakan sungai kecil atau kanal buatan yang digunakan sebagai penghubung jalur transportasi hasil bumi. Kepemilikan tatas didasarkan pada siapa pembuat tatas, baik yang dikerjakan sendiri atau yang membayar orang lain untuk membuat tatas. Pemilik tatas berhak memungut jasa pengelolaan dari orang yang memanfaatkan tatas sebagai sarana transportasi atau tempat berusaha.

Baruh atau ruak merupakan danau kecil di wilayah Sungai Sebangau yang pada umumnya dikelola oleh pemilik sungai. Penguasaan hanya sebatas pengelolaan, bukan hak milik dengan keterangan hak pengelolaan tertulis oleh Damang Kepala Adat atau Tetua Kampung.

\section{Analisa Pengaruh Program Pemberdayaan terhadap Kesejahteraan Masyarakat Kawasan Penyangga TN Sebangau}

Analisa ini dilakukan untuk mengevaluasi program pemberdayaan yang telah dilakukan di kawasan penyangga TN Sebangau. Program pemberdayaan menggunakan metode skoring terhadap masing-masing variabel modal dalam penerapan sustainable livelihood approach, yaitu pengaruh program pemberdayaan terhadap kondisi modal manusia, modal sosial, modal finansial, modal fisik dan mosal alam pada kawasan penyangga TN Sebangau.

Berdasarkan hasil analisis skoring, total nilai yang didapatkan dari masing-masing variabel adalah 960. Berdasarkan klasifikasi program, nilai tersebut dapat diartikan bahwa selama ini program pemberdayaan yag telah dilakukan belum berpengaruh besar terhadap peningkatan kesejahteraan masyarakat kawasan penyangga TN Sebangau. Beberapa hal yang menyebabkan antara lain:

a. Program pemberdayaan yang telah dilakukan memiliki pengaruh positif terhadap kualitas modal manusia khususnya para petani, namun belum memberikan perubahan terhadap masyarakat yang bermata pencaharian sebagai nelayan.

b. Program pemberdayaan tidak memberikan perubahan atau pengaruh positif pada modal sosial. Hal ini terlihat dengan masih banyak masyarakat yang meninggalkan kearifan lokal dan belum ada program terkait melestarikan kearifan lokal yang ada di kawasan TN Sebangau.

c. Program pemberdayaan pada kawasan penyangga memberikan pengaruh yang cukup positif pada modal finansial walaupun belum memperlihatkan peningkatan yang signifikan. Masyarakat petani yang telah mendapatkan pelatihan dari program pemberdayaan telah mampu berinovasi sehingga bisa meningkatkan pendapatan. Namun, pada masyarakat nelayan, kondisi pendapatan belum mengalami peningkatan karena belum adanya program yang bisa memberikan pengaruh positif pada pengembangan sektor perikanan. Selain itu belum ada program pemberdayaan yang menfasilitasi modal/dana usaha untuk pengembangan perekonomian.

d. Program pemberdayaan memberikan pengaruh positif pada modal infrastrukur namun belum maksimal dan belum merata. Beberapa program belum bisa menjangkau seluruh kawasan penyangga di TN Sebangau. Hal ini terlihat dari belum adanya sarana pendidikan dan kesehatan di permukiman nelayan serta sulitnya akses menuju ke kota.

e. Program pemberdayaan memberikan pengaruh positif terhadap kondisi modal alam namun belum memberikan perubahan yang besar. Melalui program pemberdayaan, kesadaran masyarakat semakin meningkat untuk turut serta menjaga kelestarian lingkungan. Akan tetapi pada progam tersebut belum terdapat suatu kegiatan yang mendukung pelestarian khususnya pada sungai dan hutan rawa, selain itu belum diadakannya program revitalisasi kondisi lingkungan yang telah rusak.

Maka berdasarkan penjelasan tersebut dapat terlihat jika program pemberdayaan sudah mampu memberikan dampak positif terhadap beberapa modal. Namun program pemberdayaan tersebut belum mampu membuat perubahan yang signifikan karena belum meratanya dan belum adanya bentuk pemberdayaan yang tepat dilakukan di kawasan penyangga TN Sebangau. Hal ini menyebabkan kesejahteraan masyarakat belum mengalami perubahan. Sehingga perlu adanya program pemberdayaan yang bisa menfasilitasi kondisi masyarakat kawasan penyangga saat ini.

\section{Mengidentifikasi Potensi dan Masalah di Kawasan Penyangga TN Sebangau}

Analisa potensi dan masalah dilakukan untuk mengarahkan program pemberdayaan yang tepat sesuai dengan potensi dan permasalahan yang ada di kawasan penyangga TN Sebangau. Berikut merupakan potensi dan masalah di kawasan penyangga TN Sebangau :

a. Modal manusia

Potensi modal manusia yang ada di kawasan penyangga TN Sebangau antara lain mata pencaharian utama merupakan nelayan sungai dan sudah ada program pemberdayaan yang meningkatkan kemampuan bertani masyarakat.

Sedangkan permasalahan modal manusia yang ada di kawasan penyangga TN Sebangau antara lain tingkat pendidikan masyarakat masih rendah, masyarakat hanya memiliki kemampuan menangkap ikan dan bertani, belum ada program pemberdayaan untuk penangkapan ikan dengan cara yang lebih modern dan rendahnya minat masyarakat untuk mengikuti penyuluhan dan pelatihan ketrampilan.

\section{b. Modal sosial}

Potensi modal sosial yang ada di kawasan penyangga TN Sebangau adalah adanya aturan atau norma lokal terkait tata cara memanfaatkan sumber daya alam untuk menjaga kelestarian sumber daya alam.

Sedangkan permasalahan modal sosial antara lain beberapa kearifan lokal sudah ada yang dilupakan, belum ada program pemberdayaan yang dapat menjaga dan mengembalikan kearifan lokal dan kurang 
berfungsinya lembaga atau organisasi yang ada di sekitar masyarakat TN Sebangau.

\section{c. Modal finansial}

Potensi yang ada pada modal finansial di kawasan penyangga TN Sebangau adalah adanya mata pencaharian yang dapat membantu perekonomian warga nelayan dan petani.

Sedangkan permasalahan yang ada di kawasan penyangga TN Sebangau adalah belum adanya peningkatan pendapatan secara signifikan sebagai nelayan ataupun petani dan belum ada program pemberdayaan yang memberikan bantuan modal untuk mengembangkan usalaha masyarakat penyangga TN Sebangau.

\section{d. Modal fisik}

Potensi modal fisik yang ada di kawasan penyangga TN Sebangau adalah adanya permukiman nelayan dengan ciri yang unik, sehingga dapat dijadikan ikon kawasan penyangga.

Sedangkan permasalahan dalam modal fisik antara lain banyaknya sarana dan prasarana pendukung yang kurang baik sehingga menghambat kegiatan masyarakat, program permberdayaan berupa bantuan pembangunan sarana dan prasarana belum merata, sulitnya akses menuju fasilitas di perkotaan dan masih ada kawasan permukiman nelayan yang belum dapat terlayani sarana pendidikan, kesehatan dan peribadatan.

\section{e. Modal alam}

Potensi modal alam yang ada di kawasan penyangga TN Sebangau antara lain adanya sungai di TN Sebangau yang dapat dimanfaatkan masyarakat nelayan, terdapat danau yang berpotensi untuk dijadikan kawasan wisata dan adanya hutan rawa dengan ekosistem unik yang dapat dijadikan sebagai ciri khas kawasan penyangga TN Sebangau.

Sedangkan permasalahan modal alam yang ada di kawasan penyangga TN Sebangau antara lain menurunnya kualitas hutan rawa gambut, hilangnya beberapa spesies tanaman, terancamnya keberadaan orang utan di TN Sebangau dan masih adanya pelanggaran yang dilakukan masyarakat seperti illegal logging, pembakaran hutan, perburuan liar hingga merusak kawasan taman nasional dan belum ada program mengenai upaya untuk merevitalisasi lingkungan yang telah rusak.

\section{Penentuan Alternatif Model Pemberdayaan Masyarakat di Kawasan Penyangga TN Sebangau Berdasarkan Perspektif Sustainable Livelihood}

Model pemberdayaan masyarakat di kawasan penyangga menggunakan metode analytical hierarchy process (AHP), dengan menjadikan para ahli dari pemerintah dan tokoh masyarakat sebagai narasumber penelitian. Proses AHP dilakukan dengan menggunakan 4 tingkatan/hirarki. Hirarki I adalah pemilihan model pemberdayaan di kawasan TN Sebangau. Hirarki II adalah kriteria/variabel yang berisi parameter yang menentukan suatu model pemberdayaan. Hirarki III berisi sub kriteria/sub variabel dari masing-masing kriteria pada tingkat kedua. Hirarki IV yang merupakan tingakatan pada proses AHP di penelitian ini berisi alternatif model pemberdayaan di kawasan penyangga TN Sebangau.

Variabel/kriteria yang digunakan didasarkan pada model pemberdayaan menurut Suharto [6], antara lain :

1. Orientasi tujuan

2. Struktur masyarakat dan kondisi masalah

3. Asumsi mengenai kepentingan masyarakat

4. Konsepsi mengenai kepentingan umum

5. Orientasi terhadap struktur kekuasaan

6. Sistem klien atau sistem perubahan

7. Konsepsi mengenai klien atau penerima layanan

8. Peranan masyarakat

9. Peran pekerja sosial

10. Media perubahan

11. Strategi perubahan

12. Teknik perubahan

Berdasarkan hasil AHP pada hirarki II, dapat diketahui bahwa kriteria 'peranan masyarakat' menjadi prioritas dalam menentukan model pemberdayaan. Prioritas kriteria/variabel utama ini memperoleh bobot sebesar 0.231. Prioritas kedua yaitu 'konsepsi mengenai kepentingan umum' dengan nilai bobot prioritas adalah 0,194 sedangkan prioritas terakhir yaitu 'media perubahan' dengan bobot kriteria 0,013 .

Kemudian dilakukan AHP pada hirarki III yang merupakan sub variabel/sub kriteria dari masingmasing kriteria/variabel. Berikut merupakan hasil AHP dari hiraki III :

1. Pada kriteria 'orientasi tujuan' didapatkan prioritas sub kriteria adalah 'kemandirian dan kemampuan masyarakat' dengan nilai bobot sebesar 0,737

2. Pada kriteria 'struktur masyarakat dan kondisi masalah' didapatkan prioritas sub kriteria adalah 'keseimbangan-kurang mampu memecah masalah' dengan nilai bobot sebesar 0,727

3. Pada kriteria 'asumsi mengenai kepentingan masyarakat' didapatkan prioritas sub kriteria adalah 'kepentingan umum-perbedaan dapat diselaraskan' dengan nilai bobot sebesar 0,764

4. Pada kriteria 'konsepsi mengenai kepentingan umum' didapatkan prioritas sub kriteria adalah 'rationalistunitary' dengan nilai bobot sebesar 0,790

5. Pada kriteria 'konsepsi mengenai orientasi terhadap struktur kekuasaan' didapatkan prioritas sub kriteria adalah 'struktur kekuasaan sebagai kolaborator dan perwakilan' dengan nilai bobot sebesar 0,761

6. Pada kriteria 'sistem klien atau sistem perubahan' didapatkan prioritas sub kriteria 'masyarakat secara keseluruhan' dengan nilai bobot sebesar 0,733

7. Pada kriteria 'konsepsi mengenai klien atau penerima pelayanan' didapatkan prioritas sub kriteria 'warga masyarakat' dengan nilai bobot sebesar 0,763

8. Pada kriteria 'peranan masyarakat' didapatkan prioritas sub kriteria adalah 'partisipan dalam pemecahan masalah' dengan nilai bobot yang didapatkan sebesar 0,736

9. Pada kriteria 'peran pekerja sosial' didapatkan prioritas sub kriteria adalah 'partisipan dalam pemecahan masalah' dengan nilai bobot sebesar 0,761

10. Pada kriteria 'media perubahan' didapatkan sub kriteria prioritas adalah 'mobilisasi kelompokkelompok kecil' dengan nilai bobot sebesar 0,748 
11. Pada kriteria 'strategi perubahan' didapatkan sub kriteria prioritas adalah 'pelibatan masyarakat dalam pemecahan masalah' dengan nilai bobot sebesar 0,752

12. Pada kriteria 'teknik perubahan' didapatkan sub kriteria prioritas adalah 'konsensus, diskusi kelompok, partisipasi, brain storming, role playing dll.' Dengan nilai bobot sebesar 0,743.

Langkah terakhir pada proses AHP adalah penentuan prioritas model pemberdayaan kawasan penyangga TN Sebangau yang didasarkan pada seluruh perhitungan kriteria dan subkriteria yang telah ada. Penentuan prioritas pengelolaan berdasarkan keseluruhan kriteria dan subkriteria pada 3 strategi pengelolaan kawasan penyangga dapat diinterpretasikan sebagai berikut :

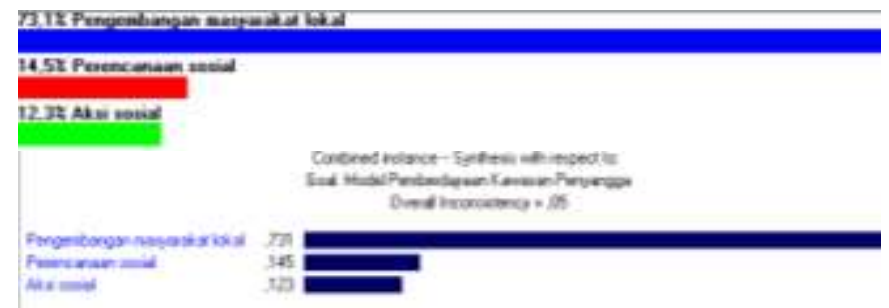

Gambar 1. Hasil AHP Pemilihan alternatif model pemberdayaan yang prioritas di Kawasan TN Sebangau pada Hirarki IV

Berdasarkan hasil analisis didapatkan bahwa model pemberdayaan yang tepat diterapkan di kawasan penyangga TN Sebangau adalah 'pengembangan masyarakat lokal'.

\section{TEMUAN ATAU DISKUSI}

Berdasarkan hasil menggali informasi dari responden di lapangan, bahwa budaya atau kearifan lokal yang ada di kawasan penyangga TN Sebangau bermanfaat untuk menjaga kelestarian ekosistem kawasan. Hal ini perlu ada kajian khusus untuk menindaklanjuti apa yang mempengaruhi minimnya masyarakat yang menerapkan kearifan lokal dalam memanfaatkan ekosistem di kesehariannya.

Selain itu, tidak dimilikinya kelembagaan atau organisasi lokal yang menaungi komunitas masyarakat penyangga di TN Sebangau juga memerlukan pendampingan. Hal ini perlu dilakukan dengan harapan, bahwa lembaga atau organisasi lokal akan membantu masyarakat untuk mendapatkan fasilitas sesuai dengan kebutuhan.

Faktor sumber daya manusia juga menjadi faktor penting yang harus dikaji lebih mendalam. Terutama kajian mengenai kemampuan dan ketrampilan dasar masyarakat yang dihubungkan dengan perilaku keseharian dan juga norma yang berlaku di masyarakat.

\section{E. SIMPULAN DAN SARAN}

Strategi pemberdayaan yang dapat diterapkan pada kawasan penyangga TN Sebangau dengan menggunakan modal manusia, social, financial, fisik, dan alam.

Pada penelitian selanjutnya dapat dilengkapi dengan faktor kebijakan yang dilakukan pemerintah daerah serta stakeholder terkait dalam meningkatkan kesejahteraan masyarakat penyangga di TN Sebangau. Hal ini akan meningkatkan akurasi langkah yang diambil dalam meningkatkan pemberdayaan masyarakat di kawasan penyangga pada penelitian ini. Perlu adanya pihak yang memfasilitasi kebutuhan masyarakat yang tinggal di kawasan penyangga TN Sebangau dengan kebiijakan-kebijakan yang dibuat oleh Kementerian Kehutanan atau pemerintah daerah. Sehingga dengan meningkatkan pemberdayaan masyarakat untuk mengelola lima modal dasar yaitu modal sosial, modal alam, modal fisik, modal manusia dan modal finansial akan membantu menyelesaikan permasalahan yang ada di kawasan penyangga TN Sebangau.

\section{DAFTAR RUJUKAN}

[1] Aqil, Ibnu, Deforestation Decreases Globally but Remains Alarming : Report, The Jakarta Post, 2020.

[2] FAO and UNEP, The State of the World's Forests 2020: Forests, biodiversity and people, Rome, 2020.

[3] Purnomo, Heri A., S. H. Suryawati, I. M. Radjawane dan K. O. Sembiring, Perubahan Ikim di Wilayah Pesisir : Konsepsi dan Aplikasi Strategi Adaptasi, Penerbit ITB, 2015.

[4] Kamaruddin, Roslina, The Sustainable Livelihoods Index: A Tool To Assess The Ability And Preparedness Of The Rural Poor In Receiving Entrepreneurial Project, Journal of Social Economics Research, 2014.

[5] Saragih, Sebastian, Lassa Jonatan dan Ramli Afan, Kerangka Penghidupan Berkelanjutan (Sustainable Livelihood Framework), 2007.

[6] Suharto,Edi, Membangun Masyarakat Memberdayakan Rakyat, 2009.

[7] Santika, Truly et al., Community Forest Management in Indonesia : Avoided Deforestation in The Context of Anthropogenic and Climate Complexities, Global Environmental Change: Elsevier, 2017.

[8] De Royer, S. et al., Does Community-Based Forest Management in Indonesia Devolve Social Justice or Social Costs?, International Forestry Review Vol.20 (2), 2018.

[9] Erbaugh, James T., Responsibilization and Social Forestry in Indonesia, Forest Policy and Economics : Elsevier, 2019. 